JURNAL NOMINAL / VOLUME VI NOMOR 2 / TAHUN 2017

\title{
PENGARUH UKURAN DEWAN KOMISARIS, KEPEMILIKAN MANAJERIAL, KEPEMILIKAN INSTITUSIONAL DAN KOMITE AUDIT TERHADAP STRUKTUR MODAL
}

\author{
Nurul Juita Thesarani \\ Prodi Akuntansi Universitas Negeri Yogyakarta \\ juita.tugas@gmail.com
}

\begin{abstract}
Abstrak: Pengaruh Ukuran Dewan Komisaris, Kepemilikan Manajerial, Kepemilikan Institusional dan Komite Audit terhadap Struktur Modal. Penelitian ini bertujuan untuk mengetahui pengaruh Ukuran Dewan Komisaris, Kepemilikan Manajerial, Kepemilikan Institusional dan Komite Audit terhadap Struktur Modal perusahaan manufaktur yang terdaftar di BEI tahun 2012-2014. Sampel dalam penelitian ini berjumlah 102 perusahaan. Teknik analisis data yang digunakan adalah analisis regresi sederhana dan analisis regresi berganda. Hasil penelitian ini menunjukkan: (1) Ukuran Dewan Komisaris berpengaruh positif dan tidak signifikan terhadap Struktur Modal, (2) Kepemilikan Manajerial berpengaruh negatif dan signifikan terhadap Struktur Modal, (3) Kepemilikan Institusional berpengaruh negatif dan tidak signifikan terhadap Struktur Modal, (4) Komite Audit berpengaruh positif dan tidak signifikan terhadap Struktur Modal, (5) Ukuran Dewan Komisaris, Kepemilikan Manajerial, Kepemilikan Institusional dan Komite Audit secara bersama-sama berpengaruh secara signifikan terhadap Struktur Modal.
\end{abstract}

Kata kunci: Ukuran Dewan Komisaris, Kepemilikan Manajerial, Kepemilikan Institusional, Komite Audit, Struktur Modal

Abstract: Effect Board Commissioners, Managerial Ownership, Institutional Ownership, Audit Committee on Capital Structure. This study aims to determine the influence of Board of Commissioners, Managerial Ownership, Institutional Ownership, and Audit Committee on Capital Structure of manufacturing company that listed on Indonesian Stock Exchange in the period of 2012-2014. Sample of this research is 102 companies. Analysis technique that used in this research is simple regression analysis and multiple linier regression. The result of this research shows that (1) The Board of Commissioners have positive and not significant influence toward Capital Structure, (2) Managerial Ownership have negative and significant influence toward Capital Structure, (3) Institutional Ownership have negative and not significant influence toward Capital Structure, (4) Audit Committee have positive and not significant influence toward Capital Structure, (5) The Board of Commissioners, Managerial Ownership, Institutional Ownership, and Audit Committee by simultant significance influence toward Capital Structure.

Keywords: Board of Commissioners, Managerial Ownership, Institutional Ownership, Audit Committee, Capital Structure

\section{PENDAHULUAN}

Perkembangan pasar modal Indonesia di sepanjang tahun 2014 menunjukkan pencapaian positif yang disertai dengan tercatatnya sejumlah rekor baru seperti yang terlansir dalam situs resmi yang diterbitkan oleh BEI. Hal ini menunjukkan bahwa masyarakat baik dalam maupun luar negeri semakin tertarik untuk menanamkan modal pada perusahaan di Indonesia. Kepercayaan masyarakat untuk menanamkan modal pada sebuah perusahaan juga harus didukung oleh pihak intern perusahaan dan pemilik saham karena meningkatnya jumlah investor di Indonesia juga akan memajukan perekonimian di Indonesia. 


\section{JURNAL NOMINAL / VOLUME VI NOMOR 2 / TAHUN 2017}

Para calon investor akan lebih tertarik menanamkan modal pada perusahaan dengan kinerja yang baik, sehingga ada perusahaan yang berusaha berbuat curang untuk mengecoh para investor. Seperti kasus skandal manipulasi laporan keuangan Bank Lippo yang terjadi pada tahun 20022003 merupakan salah gambaran dari ketidakterbukaan perusahaan terhadap investor maupun calon investor. Dengan adanya laporan keuangan yang telah dimanipulasi ini sangat merugikan pihak investor yang menganggap kinerja perusahaan ini berjalan dengan baik ternyata sebaliknya. Manajer yang seharusnya mensejajarkan kepentingan perusahaan dan pemegang saham justru merugikan pemegang saham dan menyesatkan dengan laporan keuangan yang dimanipulasi.

Salah satu sektor tebesar yang ada di Indonesia yaitu sektor manufaktur ini merupakan sektor yang paling aktif dalam memperdagangkan sahamnya pada pasar modal dan pertumbuhan sektor ini terus meningkat di Indonesia. Meningkatnya laju pertumbuhan sektor manufaktur adalah hasil dari permintaan domestik. Peluang ini mendorong perusahaan manufaktur saling bersaing untuk mengembangkan produktivitas demi memenuhi kebutuhan konsumen. Perusahaan manufaktur harus memiliki modal yang cukup untuk mengembangkan usahanya. Pemenuhan kebutuhan modal untuk membiayai aktivitas perusahaan dapat berasal dari dana internal dan dana eksternal. Apabila modal sendiri yang berasal dari kekayaan para pemilik perusahaan dirasa belum mencukupi untuk melakukan pengembangan, maka modal dari luar digunakan seperti utang jangka panjang, saham preferen, dan saham biasa. Manajer keuangan harus teliti dalam menentukan keputusan pendanaan perusahaan, agar sejalan dengan tercapainya tujuan perusahaan yaitu memaksimalkan kesejahteraan pemegang saham.

Keputusan menentukan Struktur Modal merupakan hal yang penting, karena penetuan Struktur Modal berkaitan dengan timbulnya biaya modal. Biaya modal adalah biaya yang diperlukan untuk mendapatkan modal tersebut. Penentuan Struktur Modal yang optimal membuat perusahaan berjalan dengan efektif dan efisien dengan meminimalkan biaya modal.

Terdapat dua cara dalam pemilihan modal pada perusahaan yang biasa dilakukan, pertama dengan cara melakukan pinjaman dan yang kedua adalah mengeluarkan saham. Dengan cara melakukan pinjaman memang mengeluarkan biaya yang lebih sedikit, namun hal ini akan menimbulkan risiko kewajiban dan pembayaran bunga yang meningkat. Tingkat utang yang relatif tinggi akan menimbulkan biaya tetap berupa 


\section{JURNAL NOMINAL / VOLUME VI NOMOR 2 / TAHUN 2017}

beban bunga, sehingga akan meningkatkan risiko bisnis perusahaan.

Dalam struktur modal konservatif, susunan modal menitikberatkan pada modal sendiri karena pertimbangan bahwa penggunaan utang dalam pembiayaan perusahaan mengandung risiko yang lebih besar dibandingkan dengan penggunaan modal sendiri. Sehingga banyak perusahaan yang memilih mendapatkan modal dengan cara kedua yaitu menerbitkan saham baru untuk mencari investor. Harga saham yang tinggi menunjukkan bahwa kesejahteraan pemilik perusahaan baik dan menunjukkan kinerja perusahaan juga baik. Calon investor akan lebih tertarik dengan perusahaan yang kinerjanya baik sehingga mereka akan mempercayakan investasi mereka pada perusahaan tersebut. Semakin banyaknya calon investor yang menanamkan modal pada perusahaan maka semakin sedikit pula penggunaan utang pada Struktur Modal perusahaan dan risiko pada perusahaan juga akan semakin kecil.

Perusahaan akan menunjuk manajer untuk menjalankan kegiatan usaha. Hal ini sesuai dengan penelitian dari Margaretha dan Ramadhan (2010) yang juga mengatakan bahwa keputusan pendanaan yang baik dari suatu perusahaan dapat dilihat dari Struktur Modal. Salah satu keputusan penting yang dilakukan manajer kaitannya dengan kelangsungan operasi perusahaan adalah keputusan permodalan atau keputusan pemilihan Struktur Modal yang optimal. Struktur Modal yang optimal dari perusahaan akan mampu meminimalkan biaya modal yang harus ditanggung perusahaan. Tujuan dalam pemilihan Struktur Modal perusahaan adalah untuk optimalisasi nilai perusahaan, memaksimumkan kemakmuran investor dan meminimalkan biaya modal.

Dalam hal penentuan Struktur Modal sering kali terjadi konflik antara pemegang saham dengan manajer. Perlu adanya tindakan dari perusahaan agar konflik tersebut tidak mengakibatkan efek buruk bagi perusahaan seperti kehilangan investor.

Ada beberapa pihak yang dapat berpengaruh dalam penentuan Struktur Modal perusahaan. Pada penelitian ini akan meneliti pengaruh Ukuran Dewan Komisaris, Kepemilikan Manajerial, Kepemilikan Institusional dan Komite Audit terhadap Struktur Modal perusahaan. Pada penelitian yang dilakukan oleh Kurniawan dan Rahardjo (2014) mengatakan bahwa Ukuran Dewan Komisaris dan Kepemilikan Institusional tidak berpengaruh signifikan terhadap Struktur Modal perusahaan, tetapi Kepemilikan Manajerial dan Komite Audit berpengaruh signifikan terhadap Struktur Modal perusahaan. Sedangkan pada penelitian yang dilakukan oleh Maftukhah pada tahun 2013 menyatakan bahwa 


\section{JURNAL NOMINAL / VOLUME VI NOMOR 2 / TAHUN 2017}

Kepemilikan Manajerial menunjukkan pengaruh negatif dan signifikan terhadap strukur modal dan Kepemilikan Institusional menunjukkan pengaruh positif dan signifikan terhadap Struktur Modal.

Saat ini pemegang saham menginginkan manajer bekerja dengan tujuan memaksimumkan kemakmuran pemegang saham. Hal ini sesuai dengan pendapat Menurut Jensen dan Meckling (1976) dalam Kusuma (2005), yaitu para pemegang saham berharap agen akan bertindak atas kepentingan mereka. Sebaliknya manajer perusahaan bisa saja memiliki tujuan lain yang bertentangan dengan tujuan pemegang saham. Dengan adanya pengawasan dari perusahaan yang baik memberikan perlindungan efektif kepada para pemegang saham dan pihak kreditor, sehingga mereka bisa meyakinkan dirinya akan perolehan kembali investasinya dengan wajar dan bernilai tinggi. Oleh karena itu, pengawasan tersebut juga harus membantu menciptakan lingkungan yang kondusif terhadap pertumbuhan sektor usaha yang efisien dan berkesinambungan.

\section{METODE PENELITIAN}

\section{Jenis Penelitian}

Jenis penelitian ini adalah kausal komparatif (causal comparative research) dengan menggunakan pendekatan kuantitatif karena mengacu pada perhitungan data berupa angka. Data yang digunakan adalah data sekunder yang diperoleh dari website resmi Bursa Efek Indonesia (www.idx.co.id), website resmi ICAMEL, serta literatur-literatur lain yang mendukung terkait masalah yang diteliti.

\section{Waktu dan Tempat Penelitian}

Penelitian ini akan dilakukan dengan melakukan pengambilan data dengan mengakses web idx dan icamel dalam bentuk online dan bisa diakses tanpa ada batasan waktu tertentu. Waktu yang digunakan untuk melakukan peneitian ini dilakukan pada bulan Januari-Maret 2016.

\section{Populasi dan Sampel}

Populasi yang digunakan dalam penelitian ini adalah perusahaan manufaktur yang listing di Bursa Efek Indonesia (BEI) periode penelitian 20122014. Pengambilan keputusan dalam sampel ini dilakukan dengan menggunakan purposive sampling, yaitu penentuan sampel berdasarkan pertimbangan tertentu. Sampel penelitian ini diambil dari perusahaan yang terdaftar di Bursa Efek Indonesia (BEI) dengan periode 2012-2014. Total sampel yang digunakan dalam penelitian ini adalah 102 perusahaan ( 34 x 3 tahun).

\section{Definisi Operasional Variabel}

Struktur Modal

Struktur Modal merupakan perimbangan jumlah kewajiban jangka 


\section{JURNAL NOMINAL / VOLUME VI NOMOR 2 / TAHUN 2017}

pendek yang bersifat permanen, kewajiban jangka panjang, saham preferen, dan saham biasa (Sartono, 2001). Dalam penelitian ini, untuk mengukur Struktur Modal dengan menggunakan debt to equity ratio (DER). DER ini merupakan besaran persentase total utang perusahaan dibandingkan dengan total ekuitas perusahaan.

Struktur Modal dihitung dengan DER, dengan rumus:

$$
\mathrm{DER}=\frac{\text { Total Debt }}{\text { Total Equity }}
$$

Ukuran Dewan Komisaris

Dewan komisaris merupakan mekanisme pengendalian intern tertinggi yang bertanggung jawab untuk memonitor tindakan manajemen puncak (Fama dan Jensen: 1983). Dewan komisaris sebagai organ perusahaan bertugas dan bertanggung jawab secara kolektif untuk melakukan pengawasan dan memberikan nasihat kepada direksi serta memastikan bahwa perusahaan melaksanakan GCG (KNKG, 2006). Ukuran Dewan Komisaris yang dimaksud disini adalah banyaknya jumlah anggota dewan komisaris dalam suatu perusahaan.

Kepemilikan Manajerial

Kepemilikan Manajerial adalah jumlah kepemilikan saham oleh pihak manajemen dari seluruh modal saham perusahaan yang dikelola (Boediono: 2005). Indikator yang digunakan untuk mengukur Kepemilikan Manajerial adalah persentase jumlah saham yang dimiliki pihak manajemen dari seluruh modal saham perusahaan yang beredar.

Kepemilikan Institusional

Kepemilikan Institusional merupakan saham perusahaan yang dimiliki oleh institusi atau lembaga. Indikator yang digunakan untuk mengukur Kepemilikan Institusional adalah persentase jumlah saham, yang dimiliki pihak institusional dari seluruh modal saham perusahaan yang beredar.

Komite Audit

Komite Audit adalah auditor internal yang dibentuk dewan komisaris, yang bertugas melakukan pemantauan dan evaluasi atas perencanaan dan pelaksanaan pengendalian intern perusahaan. Indikator yang digunakan untuk mengukur Komite Audit adalah jumlah anggota Komite Audit pada perusahaan sampel.

\section{Metode Pengumpulan Data}

Penelitian ini menggunakan data annual report dan financial report tahun 2012-2014 yang bersumber dari website http://www.icamel.id. Sesuai dengan jenis data yang diperlukan yaitu data sekunder, maka metode pengumpulan data dalam penelitian ini adalah dengan metode dokumentasi. Metode dokumentasi dilakukan dengan cara memperoleh data dengan menggunakan dokumentasi yang berdasarkan pada annual report perusahaan yang dipublikasikan oleh BEI dan ICAMEL 


\section{JURNAL NOMINAL / VOLUME VI NOMOR 2 / TAHUN 2017}

di situsnya www.idx.co.id dan www.icamel.id dan BEI Yogyakarta.

\section{Teknik Analisis Data}

Statistik Deskriptif

Statistik deskriptif dilakukan untuk memberikan gambaran atau deskripsi suatu data yang dilihat dari nilai rata-rata (mean), standar deviasi, varian, maksimum, minimum, sum, range, kurtosis, dan skewness (kemencangan distribusi).

Uji Asumsi Klasik

Uji Normalitas

Uji normalitas adalah untuk melihat apakah nilai residual terdistribusi normal atau tidak. Model regresi yang baik adalah memiliki nilai residual yang terdistribusi normal. Jadi uji normalitas bukan dilakukan pada masing-masing variabel tetapi pada nilai residualnya.

\section{Uji Multikolonieritas}

Multikolonieritas adalah keadaan di mana terjadi hubungan linear yang sempurna atau mendekati sempurna antar variabel independen dalam model regresi (nilai korelasi 1 atau mendekati 1). Model regresi yang baik adalah yang tidak ada masalah multikolonieritas (Priyatno: 2013).

\section{Uji Heteroskedastisitas}

Uji heteroskedastisitas adalah untuk melihat apakah terdapat ketidaksamaan varians dari residual satu ke pengamatan ke pengamatan yang lain. Model regresi yang memenuhi persyaratan adalah di mana terdapat kesamaan varians dari residual satu pengamatan ke pengamatan yang lain tetap atau disebut homoskedastisitas.

\section{Uji Autokorelasi}

Uji autokorelasi adalah untuk melihat ada atau tidaknya penyimpangan asumsi klasik autokorelasi, yaitu korelasi yang terjadi antara residual pada satu pengamatan dengan pengamatan lain pada model regresi. Model regresi dianggap baik jika regresinya bebas dari autokorelasi (Ghozali: 2011).

\section{Pengujian Hipotesis}

1) Analisis Regresi Linier Sederhana digunakan untuk uji hipotesis 1, 2, 3 dan 4 yaitu mengetahui pengaruh parsial Ukuran Dewan Komisaris terhadap Struktur Modal, Kepemilikan Manajerial terhadap Struktur Modal, Kepemilikan Institusional terhadap Struktur Modal serta Komite Audit terhadap Struktur Modal. Pengujian hipotesis diawali dengan menentukan persamaan linier sederhana, kemudian menentukan koefisien determinasi $\left(\mathrm{r}^{2}\right)$ untuk mengetahui seberapa jauh kemampuan variasi variabel independen dalam menerangkan variasi variabel dependen. Setelah itu menguji tingkat pengaruh dengan uji t.

2) Analisis Regresi Linier Berganda digunakan untuk uji hipotesis kelima, 


\section{JURNAL NOMINAL / VOLUME VI NOMOR 2 / TAHUN 2017}

yaitu mengetahui pengaruh Ukran

Dewan Komisaris, Kepemilikan Manajerial,

Kepemilikan

Institusional dan Komite Audit secara simultan terhadap Struktur Modal. Pengujian hipotesis ini diawali dengan menentukan persamaan regresi linier berganda, kemudian menentukan koefisien determinasi $\left(\mathrm{R}^{2}\right)$. Terakhir, menguji tingkat korelasi dengan uji F.

HASIL PENELITIAN DAN PEMBAHASAN

Variabel yang diukur dalam penelitian ini diproksikan dengan Struktur Modal (DER)), Ukuran Dewan Komisaris (DK), Kepemilikan Manajerial (KM), Kepemilikan Institusional (KI), dan Komite Audit (KA).

Berdasarkan pengujian asumsi klasik, diperoleh hasil bahwa data telah memenuhi syarat asumsi klasik, kecuali pada uji normalitas. Sehingga, penelitian ini membuang beberapa data yang menjadi outlier. Selanjutnya, pengujian dilakukan dengan menggunakan analisis regresi linier sederhana dan analisis regresi linier berganda. Berikut ini merupakan hasil analisis regresi linier:

Tabel 1. Ringkasan Hasil Uji Hipotesis 1

\begin{tabular}{lccccc}
\hline $\begin{array}{c}\text { Varia } \\
\text { bel }\end{array}$ & B & Beta & \multicolumn{3}{c}{ Nilai t } \\
\cline { 3 - 6 } & & & $\mathrm{t}_{\text {hitung }}$ & $\mathrm{t}_{\text {tabel }} \cdot$ & Sig. \\
\hline DK & 1,00 & 0,010 & 0,312 & 1,660 & 0,756 \\
1 & 9 & & & 6 & \\
\hline
\end{tabular}

Berdasarkan tabel 1, persamaan regresi adalah:

$\mathrm{DER}=1,009+0,010 \mathrm{DK}$

Berdasarkan tabel 1, dapat dilihat bahwa $t_{\text {hitung }}$ sebesar 0,312 sedangkan $t_{\text {tabel }}$ pada tingkat signifikansi $5 \%$ sebesar 1,6606. Hasil ini menunjukkan bahwa $t_{\text {hitung }}$ lebih kecil dari $t_{\text {tabel }}(0,312<1,6606)$. Nilai probabilitas signifikansi sebesar 0,756 menunjukkan nilai yang lebih besar dari nilai pada tingkat signifikansi yang telah ditentukan sebelumnya, yaitu 0,05 (0,756 > 0,05). Berdasarkan hasil uji hipotesis ini dapat disimpulkan bahwa hipotesis pertama (H1) ditolak atau variabel Dewan Komisaris tidak memiliki pengaruh negatif dan signifikan teradap Struktur Modal.

Hasil penelitian ini sesuai dengan penelitian Kurniawan dan Rahardjo (2014) yang mengatakan bahwa Ukuran Dewan Komisaris tidak berpengaruh signifikan terhadap Struktur Modal perusahaan. Hasil $\mathrm{t}$ hitung yang positif menunjukkan pengaruh yang positif antara Ukuran Dewan Komisaris dan Struktur Modal. Hal ini sesuai dengan penelitian oleh Fauma Hidayatullah yang menunjukkan pengaruh positif antara Dewan Komisaris dengan Struktur Modal. Tidak signifikan Ukuran Dewan Komisaris terhadap Struktur Modal kemungkinan disebabkan karena kurang efektifnya Dewan Komisaris dalam menjalankan pengawasan dan kontrol pada operasional perusahaan, sehingga 


\section{JURNAL NOMINAL / VOLUME VI NOMOR 2 / TAHUN 2017}

penentuan mekanisme pendanaan atau modal perusahaan lebih banyak ditentukan oleh dewan direksi.

Tabel 2. Ringkasan Hasil Uji Hipotesis 2

\begin{tabular}{lccccc}
\hline $\begin{array}{l}\text { Vari } \\
\text { abel }\end{array}$ & B & Beta & \multicolumn{3}{c}{ Nilai t } \\
\cline { 3 - 6 } & & & $\mathrm{t}_{\text {hitung }}$ & $\mathrm{t}_{\text {tabel }} \cdot$ & Sig. \\
\hline KM & 1,22 & - & - & 1,66 & 0,00 \\
1 & 2 & 3,436 & 3,263 & 06 & 2 \\
\hline
\end{tabular}

Berdasarkan tabel 2, persamaan regresi adalah:

$$
\mathrm{DER}=1,222-3,436 \mathrm{KM}
$$

Berdasarkan tabel 2, dapat dilihat bahwa $t_{\text {hitung }}$ sebesar $-3,263$ sedangkan $t_{\text {tabel }}$ pada tingkat signifikansi $5 \%$ sebesar 1,6606. Hasil ini menunjukkan bahwa thitung lebih kecil dari $\mathrm{t}_{\text {tabel }}(-3,263<1,6606)$. Nilai probabilitas signifikansi sebesar 0,002 menunjukkan nilai yang lebih kecil dari nilai pada tingkat signifikansi yang telah ditentukan sebelumnya, yaitu 0,05 $(0,002<$ 0,05). Berdasarkan hasil uji hipotesis ini dapat disimpulkan bahwa hipotesis kedua (H2) diterima atau variabel Kepemilikan Manajerial memiliki pengaruh negatif dan signifikan teradap Struktur Modal.

Hasil penelitian ini sesuai dengan penelitian Faumana Hidayatullah (2013) menyatakan bahwa Kepemilikan Manajerial berpengaruh terhadap Struktur Modal. Pada hasil penelitian tersebut mengindikasikan bahwa perusahaan yang sebagian sahamnya dimiliki oleh manajemen memiliki kecenderungan menerapkan kebijakan utang yang kecil.
Hal tersebut dikarenakan manajemen ikut menanggung biaya modal yang ditanggung perusahaan. Kepemilikan Manajerial akan mensejajarkan kedudukan manajer dengan pemegang saham lainnya, sehingga akan bertindak selaras dengan pemegang saham lainnya (Sheikh dan Wang : 2012). Selain itu manajer akan merasakan langsung manfaat dan kerugian dari keputusan yang diambil. Pendanaan yang bersumber dari kewajiban menjadi tidak menarik bagi para manajer karena akan membebankan risiko yang lebih tinggi bagi dirinya (Sheikh dan Wang : 2012).

Tabel 3. Ringkasan Hasil Uji Hipotesis 3

\begin{tabular}{lccccc}
\hline Vari & B & Beta & \multicolumn{3}{c}{ Nilai t } \\
\cline { 3 - 6 } & & & $\mathrm{t}_{\text {hitung }}$ & $\mathrm{t}_{\text {tabel }} \cdot$ & Sig. \\
\hline KI & 1,30 & - & - & 1,66 & 0,4 \\
$\backslash$ & 6 & 0,372 & 0,821 & 06 & 14 \\
\hline
\end{tabular}

Berdasarkan tabel 3, persamaan regresi adalah:

$\mathrm{DER}=1,306-0,372 \mathrm{KI}$

Berdasarkan tabel 3, dapat dilihat bahwa $t_{\text {hitung }}$ sebesar $-0,821$ sedangkan $t_{\text {tabel }}$ pada tingkat signifikansi $5 \%$ sebesar 1,6606. Hasil ini menunjukkan bahwa $t_{\text {hitung }}$ lebih kecil dari $\mathrm{t}_{\text {tabel }}(-0,821<1,6606)$. Nilai probabilitas signifikansi sebesar 0,414 menunjukkan nilai yang lebih besar dari nilai pada tingkat signifikansi yang telah ditentukan sebelumnya, yaitu 0,05 (0,414 > 0,05). Berdasarkan hasil uji hipotesis ini dapat disimpulkan bahwa hipotesis ketiga (H3) diterima atau variabel Kepemilikan 


\section{JURNAL NOMINAL / VOLUME VI NOMOR 2 / TAHUN 2017}

Institusional memiliki pengaruh negatif dan tidak signifikan teradap Struktur Modal.

Hasil penelitian ini mendukung penelitian Fauma Hidayatullah (2013) menyatakan bahwa Kepemilikan Institusional berpengaruh terhadap Struktur Modal. Kepemilikan saham oleh intitusi atau pemerintah ini dianggap dapat meminimalkan penggunaan utang dalam Struktur Modal. Kepemilikan Institusional dapat mengurangi konflik keagenan karena mampu mengontrol dan mengarahkan manajer untuk membuat kebijakan utang dan deviden yang berpihak pada kepentingan pemegang saham institusional. Hal ini berarti semakin besar saham yang dimiliki oleh investor institusional akan menyebabkan usaha monitoring menjadi semakin efektif karena dapat mengendalikan perilaku opportunistik yang dilakukan oleh para manajer (Jensen: 1986). Pengawasan yang efektif akan membantu para investor dan calon investor mempercayai perusahaan untuk menanamkan modal pada perusahaan tersebut. Kepemilikan Institusional yang kuat akan mampu mengontrol kebijakan manajemen atas arus kas perusahaan, dan mencegah manajer dalam penggunaan dana yang kurang efisien.

Tabel 4. Ringkasan Hasil Uji Hipotesis 4

\begin{tabular}{llllcc}
\hline $\begin{array}{c}\text { Variab } \\
\text { el }\end{array}$ & B & Beta & \multicolumn{3}{c}{ Nilai t } \\
\cline { 4 - 6 } & & & thitung $_{\text {tabel }}$ & Sig. \\
\hline KA & 0,50 & 0,17 & 0,696 & 1,66 & 0,488 \\
I & 5 & 7 & & 06 & \\
\hline
\end{tabular}
regresi adalah:

Berdasarkan tabel 4, persamaan

$\mathrm{DER}=0,505+0,177 \mathrm{KA}$

Berdasarkan tabel 4, dapat dilihat bahwa $t_{\text {hitung }}$ sebesar 0,696 sedangkan $t_{\text {tabel }}$ pada tingkat signifikansi $5 \%$ sebesar 1,6606. Hasil ini menunjukkan bahwa thitung lebih kecil dari $t_{\text {tabel }}(0,696<1,6606)$. Nilai probabilitas signifikansi sebesar 0,484 menunjukkan nilai yang lebih besar dari nilai pada tingkat signifikansi yang telah ditentukan sebelumnya, yaitu 0,05 (0,484 > 0,05). Berdasarkan hasil uji hipotesis ini dapat disimpulkan bahwa hipotesis keempat (H4) ditolak atau variabel Komite Audit tidak memiliki pengaruh negatif dan signifikan teradap Struktur Modal (DER).

Hasil penelitian yang mendukung adalah penelitian yang dilakukan oleh Rianingsih (2008) yang menyatakan bahwa perusahaan yang memiliki Komite Audit akan memiliki peringkat surat utang yang lebih tinggi daripada perusahaan yang tidak memiliki Komite Audit. Hal ini menunjukkan bahwa Komite Audit berpengaruh positif terhadap debt ratio. Variabel Komite Audit berpengaruh tidak signifikan terhadap Struktur Modal. Tidak signifikannya Komite Audit kemungkinan mengindikasikan bahwa semakin banyak jumlah Komite Audit, tidak menunjukkan peningkatan pengawasan atas kinerja manajemen. Jika dilihat dari data penelitian sebagian besar susunan Komite Audit terdiri dari 2 anggota dan 1 ketua 


\section{JURNAL NOMINAL / VOLUME VI NOMOR 2 / TAHUN 2017}

merangkap komisaris independen. Ini menunjukkan bahwa pembentukan Komite Audit hanya sebatas untuk memenuhi regulasi saja, sehingga efektifitas dalam fungsi pengawasan ini belum mampu mempengaruhi Struktur Modal perusahaan.

Tabel 5. Ringkasan Hasil Uji Hipotesis 5

\begin{tabular}{|c|c|c|c|c|c|}
\hline $\begin{array}{l}\text { Vari } \\
\text { abel }\end{array}$ & B & Beta & $\mathbf{R}^{2}$ & $\mathbf{F}_{\text {hitung }}$ & Sig. \\
\hline DK & 2,4 & 0,017 & 0,1 & 4,222 & 0,0 \\
\hline KM & 93 & $-4,667$ & 47 & & 03 \\
\hline KI & & $-1,144$ & & & \\
\hline KA & & $-0,167$ & & & \\
\hline
\end{tabular}

Berdasarkan tabel 5, persamaan regresi adalah:

$\mathrm{DER}=2,493+0,017 \mathrm{DK}-4,667 \mathrm{KM}$ - 1,144KI- 0,167KA

Berdasarkan tabel 5, dapat dilihat bahwa $F_{\text {hitung }}$ sebesar 4,222 sedangkan $F_{\text {tabel }}$ pada tingkat signifikansi $5 \%$ sebesar 2,4645. Hasil ini menunjukkan bahwa $F_{\text {hitung }}$ lebih besar dari $F_{\text {tabel }}(4,222>2,4645)$. Nilai probabilitas signifikansi sebesar 0,003 menunjukkan nilai yang lebih kecil dari nilai pada tingkat signifikansi yang telah ditentukan sebelumnya, yaitu 0,05 $(0,003<$ 0,05). Dengan nilai probabilitas yang lebih kecil dari tingkat signifikansi tersebut, maka model regresi ini dapat digunakan untuk memprediksi Struktur Modal (DER). Berdasarkan hasil hipotesis tersebut dapat disimpulkan bahwa variabel Ukuran Dewan Komisaris, Kepemilikan Manajerial, Kepemilikan Institusional dan Komite
Audit secara bersama-sama berpengaruh terhadap Struktur Modal Perusahaan.

Dewan Komisaris yang merupakan mekanisme pengendalian tertinggi ini dapat memonitor tindakan manajemen dalam menentukan keputusan pendanaan perusahaan melalui utang atau modal sendiri melalui penerbitan saham. Kepemilikan saham bisa dimiliki oleh manajer perusahaan dan institusi. Kepemilikan Manajerial yang salah satu pemilik sahamnya adalah Dewan Komisaris ini dapat mengurangi konflik antara manajemen dan pemilik saham lainnya dan akan mensejajarkan kepentingan pemilik saham. Dengan adanya kepemilikan saham oleh manajemen ini akan lebih memilih Struktur Modal dengan modal sendiri dibanding dengan menggunakan utang karena resiko yang ditanggung dari utang tergolong besar. Kepemilikan Institusional pada perusahaan akan meningkatkan pengawasan dan akan meningkatkan kepercayaan para investor eksternal. Komite Audit yang dibentuk oleh Dewan Komisaris untu melakukan pemantauan evaluasi atas perencanaan dan pengendalian intern perusahaan ini akan mengontrol perilaku manajemen yang juga akan melindungi hak para pemegang saham lainnya. Sehingga kepercayaan para pemegang saham akan meningkat. Oleh karena itu, Ukuran Dewan Komisaris, Kepemilikan Manajerial, Kepemilikan 


\section{JURNAL NOMINAL / VOLUME VI NOMOR 2 / TAHUN 2017}

Institusional dan Komite Audit akan secara bersama-sama berpengaruh terhadap Struktur Modal

\section{SIMPULAN DAN SARAN}

\section{Simpulan}

1. Secara parsial Ukuran Dewan Komisaris berpengaruh positif dan tidak signifikan terhadap Stuktur Modal perusahaan. Hal ini ditunjukkan dengan nilai koefisien yang bernilai positif sebesar 0,010 dan nilai t hitung sebesar 0,312 serta nilai signifikansinya sebesar 0,756 yang nilainya di atas 0,05 .

2. Secara parsial Kepemilikan Manajerial berpengaruh negatif dan signifikan terhadap Stuktur Modal perusahaan. Hal ini ditunjukkan dengan nilai koefisien yang bernilai negatif sebesar $-3,436$ dan nilai $t$ hitung sebesar -3,263 serta nilai signifikansinya sebesar 0,002 yang nilainya di bawah 0,05 .

3. Secara parsial Kepemilikan Institusional berpengaruh negatif dan tidak signifikan terhadap Stuktur Modal perusahaan. Hal ini ditunjukkan dengan nilai koefisien yang bernilai sebesar 1,306 dan nilai t hitung sebesar $-0,821$ serta nilai signifikansinya sebesar 0,414 yang nilainya di atas 0,05 .
4. Secara parsial Komite Audit tidak berpengaruh positif dan tidak signifikan terhadap Stuktur Modal perusahaan. Hal ini ditunjukkan dengan nilai koefisien yang bernilai positif sebesar 0,505 dan nilai thitung sebesar $\quad 0,696$ serta nilai signifikansinya sebesar 0,488 yang nilainya di atas 0,05 .

5. Secara bersama - sama Ukuran Dewan Komisaris $\left(\mathrm{X}_{1}\right)$, Kepemilikan Manajerial $\quad\left(\mathrm{X}_{2}\right), \quad$ Kepemilikan Institusional $\left(\mathrm{X}_{3}\right)$ dan Komite Audit $\left(\mathrm{X}_{4}\right)$, berpengaruh secara signifikan terhadap Struktur Modal pada perusahaan manufaktur di Bursa Efek Indonesia. Besarnya pengaruh keempat variabel bebas tersebut adalah sebesar $14,7 \%$, sedangkan sisanya $85,3 \%$ dipengaruhi oleh variabel bebas lainnya.

\section{Saran}

Berdasarkan kesimpulan di atas, dapat diusulkan saran yang diharapkan akan bermanfaat bagi penelitian selanjutnya:

1. Bagi Perusahaan

Bagi perusahaan sebaiknya dalam menentukan kebijakan utang perusahaan harus melihat beberapa faktor yang penting bagi perusahaan seperti Kepemilikan Manajerial dan Kepemilikan Institusional agar Struktur Modal ini dapat dimanfaatkan secara efektif dan efisien untuk menghasilkan kinerja yang baik. 


\section{JURNAL NOMINAL / VOLUME VI NOMOR 2 / TAHUN 2017}

Perusahaan sebaiknya dapat menurunkan penggunaan utang jika tingkat profitabilitasnya sudah cukup baik, sehingga beban perusahaan yang berasal dari utang dapat dikurangi dengan laba perusahaan.

\section{Bagi Peneliti Selanjutnya}

Peneliti memberikan saran untuk penelitian selanjutnya, terdapat beberapa hal yang perlu diperhatikan diantaranya yaitu dengan kecilnya pengaruh keempat variabel independen (ukuran dewan komisaris, kepemilikan manajerial, kepemilikan institusional dan komite audit) mampu menjelaskan variabel struktur modal (DER) maka perlu menambahkan variabel-variabel lain. Selain itu perlu menambahkan jumlah sampel dalam waktu pengamatan yang lebih lama sehingga nantinya diharapkan hasil yang diperoleh akan lebih dapat digeneralisasikan. Sektor yang digunakan juga bisa selain manufaktur, bisa digunakan sektor perbankan atau lain sebagainya sebagai populasi dari penelitian.

\section{DAFTAR PUSTAKA}

Agus Sartono. (2001). Manajemen Keuangan (Teori dan Aplikasi) Edisi Keempat. Yogyakarta: BPFE.

Duwi Priyatno. (2013). Olah Data Statistik dengan Program PSPP (sebagai alternatif SPSS. Yogyakarta: MediaKom.
Fama, Eugene, and Michael Jensen. (1983). "Separation of Ownership and Control". Journal of Law and Economics 26. Hlm 301-325.

Faumana Hidayatullah. (2013). "Pengaruh Kepemilikan Institusional, Kepemilikan Manajerial, Ukuran Dewan Komisaris, dan Jumlah Rapat Dewan Komisaris terhadap Struktur Modal". Skripsi Universitas Brawijaya Malang.

Farah Margaretha dan Aditya Rizky Ramadhan. (2010). "Faktor-faktor yang Memengaruhi Struktur Modal pada Industri Manufaktur di Bursa Efek Indonesia”. Jurnal Bisnis dan Akuntansi. Vol 12 no 2.

Ida Maftukhah. (2013). "Kepemilikan Manajerial, Kepemilikan Institusional, dan Kinerja Keuangan Sebagai Penentu Struktur Modal Perusahaan". Jurnal dinamika manajemen. Vol 4 no 1. Hlm 69-81.

Imam Ghozali. (2006). Aplikasi analisis mutivariat dengan SPSS. Badan Penerbitan Universitas Diponegoro: Semarang.

Jensen, M. C \& W. H. Meckling. (1976). "Theory of The Firm: Managerial Behavior, Agency Costs and Ownership Structure." Journal of Financial Economics, Vol. 3, No. 4. h.305-360.

Jensen, M. C. (1986). Agency Cost Of Free Cash Flow, Corporate finance, and Take Over. American Economic Review. Vol. 76, No. 2, pp: 323329.

Rianingsih. (2008). "Pengaruh Praktek Corporate Governance terhadap Risiko Kredit, Yield Surat Utang (Obligasi)". Simposium Nasional Akuntansi XI Pontianak. 
Sheikh, Nadeem Ahmed dan Zongjun Wang. (2012). "Determinants of Struktur modal An Empirical Study of Firms in Manufacturing Industry of Pakistan". Journal Managerial Finance, (37):117-133.

Vito Janitra Kurniawan dan Shiddiq Nur Rahardjo. (2014). Pengaruh antara Tata Kelola Perusahaan (Corporate Governance) dengan Struktur Modal Perusahaan. Diponegoro Journal of Accounting. Vol 3 N0 2 hlm 1-9.

Wahidahwati. (2002). Pengaruh Kepemilikan Manajerial dan Kepemilikan Institusional pada Kebijakan Utang Perusahaan: sebuah Perspektif Theory Agency. Jurnal Riset Akuntansi Indonesia. Vol. 5. No. 1. 